\title{
STRATEGI IMPLEMENTASI APLIKASI SISTEM KEUANGAN DESA: STUDI KASUS PEMERINTAH DAERAH KABUPATEN NGANJUK
}

\author{
Zaenal Fanani \\ fanani@feb.unair.ac.id \\ Departemen Akuntansi Fakultas Ekonomi dan Bisnis Universitas Airlangga
}

\begin{abstract}
This study aims to explore the strategy of implementing the village financial system application: a case study of the district government of Nganjuk. The formulation of the problem of this study is how is the implementation and assistance of Nganjuk District village financial management? how did the workshop affect the village financial management of Nganjuk Regency? how is the problem of village financial management in Nganjuk Regency (positive and negative aspects)? The research method was carried out a case study at the Nganjuk Regency Community and Village Empowerment Office (PMD). Data obtained from interviews with informants related to village financial management and observation. The results of the study show that the strategy for implementing the village financial system in Nganjuk district government by using this workshop was very effective and efficient. Problems in the village financial management of Nganjuk Regency are divided into 2 things, positive and negative aspects. Positive aspects include the synergy between the sub-district head, the PMD service, the legal bureau and the inspectorate, the ability of village operators to operate the system (SILOKDES), the completeness of village financial management regulations. Negative aspects include non-compliance with the cycle and delays in disbursing funds, capacity and personnel, non-labor-based development and not fully describing the needs of the village, and the transparency of the plans for the use and accountability of the Village Budget.
\end{abstract}

Key words: workshop, mentoring, positive aspects, negative aspects

\begin{abstract}
ABSTRAK
Penelitian ini bertujuan untuk mengupas strategi implementasi aplikasi sistem keuangan desa: studi kasus pemerintah daerah kabupaten nganjuk. Adapun rumusan masalah penelitian ini adalah bagaimana pelaksanaan dan pendampingan pengelolaan keuangan desa Kabupaten Nganjuk? bagaimana dampak workshop terhadap pengelolaan keuangan desa Kabupaten Nganjuk? bagaimanakah problematika pengelolaan keuangan desa Kabupaten Nganjuk (aspek positif dan negatif)? Metode penelitian dilakukan studi kasus pada Dinas Pemberdayaan Masyarakat dan Desa (PMD) Kabupaten Nganjuk. Data didapatkan dari hasil wawancara dengan informan yang berhubungan dengan pengelolaan keuangan desa dan observasi. Hasil penelitian menunjukkan strategi implementasi aplikasi sistem keuangan desa pada pemerintah daerah kabupaten Nganjuk dengan menggunakan workshop ini sangat efektif dan efisien. Problematika pengelolaan keuangan desa Kabupaten Nganjuk terbagi menjadi 2 hal yaitu aspek positif dan aspek negatif. Aspek positif meliputi sinergi antara camat, dinas PMD, biro hukum dan inspektorat, kemampuan operator desa mengoperasikan sistem (SILOKDES), kelengkapan peraturan pengelolaan keuangan desa. Aspek negatif meliputi ketidakpatuhan tehadap siklus dan keterlambatan pencairan dana, kapasitas dan personalia, pembangunan tidak berbasis padat karya dan tidak sepenuhnya menggambarkan kebutuhan yang diperlukan desa, dan transparansi rencana penggunaan dan pertanggungjawaban APBDesa masih rendah.
\end{abstract}

Kata kunci: workshop, pendampingan, aspek positif, aspek negatif

\section{PENDAHULUAN}

Dengan disahkannya UU No. 6 tahun 2014 tentang Desa pada tanggal 15 Januari
2014, pengaturan tentang desa mengalami perubahan secara signifikan. Dari sisi regulasi, desa (atau dengan nama lain telah 
diatur khusus atau tersendiri) tidak lagi menjadi bagian dari UU No. 32 tahun 2004 tentang Pemerintahan Daerah. Desa-desa di Indonesia akan mengalami reposisi dan pendekatan baru dalam pelaksanaan pembangunan dan tata kelola pemerintahannya. Pada hakikatnya UU Desa memiliki visi dan rekayasa yang memberikan kewenangan luas kepada desa di bidang penyelenggaraan pemerintahan desa, pelaksanaan pembangunan desa, pembinaan kemasyarakatan desa, dan pemberdayaan masyarakat desa berdasarkan prakarsa masyarakat, hak asal usul, dan adat istiadat desa.

UU Desa juga memberi jaminan yang lebih pasti bahwa setiap desa akan menerima dana dari pemerintah melalui anggaran negara dan daerah yang jumlahnya berlipat, jauh diatas jumlah yang selama ini tersedia dalam anggaran desa. Kebijakan ini memiliki konsekuensi terhadap proses pengelolaannya yang seharusnya dilaksanakan secara profesional, efektif dan efisien, serta akuntabel yang didasarkan pada prinsip-prinsip manejemen publik yang baik agar terhindarkan dari resiko terjadinya penyimpangan, penyelewengan dan korupsi. Penelitian yang membahas implementasi UU desa ini telah dilakukan oleh Ferina (2016); Badaruddin dan Ermansyah (2017); dan Badaruddin dan Ermansyah (2018).

Pemerintah dan DPR memiliki komitmen yang kuat terkait kebijakan ini, yang dibuktikan dengan telah disetujuinya anggaran dana desa Tahun 2015, pemerintah sudah menggelontorkan $\mathrm{Rp}$ 20,76 triliun untuk dana desa. Sementara, 2016 meningkat menjadi Rp 45,98 triliun. Adapun tahun 2017 sebanyak Rp 60 triliun yang akan disalurkan ke 74.093 desa di seluruh Indonesia.

Pemerintah menargetkan agar anggaran tersebut dapat segera tersalurkan ke seluruh desa. Selain menerima dana langsung dari Pusat, sumber pembiayaan keuangan desa yang besar juga berasal dari transfer dana pusat melalui APBD yang dikenal dengan Alokasi Dana Desa (ADD). Berdasarkan PP No. 43 tahun 2014, formulasi perhitungan alokasi dana desa adalah minimal $10 \%$ dari dana transfer pusat ke daerah dikurangi Dana Alokasi Khusus (DAK). Dengan menggunakan formulasi tersebut, jika menggunakan data dalam Perpres No. 162 tahun 2014 tentang besaran jumlah transfer dana dari pusat ke daerah, maka terdapat potensi antara Rp30-40 triliun dana yang mengalir ke desa dengan menggunakan mekanisme ADD.

Dari mekanisme Dana Desa (DD) dan ADD, dana sebesar kurang lebih Rp50-60 triliun akan mengalir ke 74.093 desa. Mengacu pada banyaknya kasus korupsi yang terjadi dalam proses pendistribusian anggaran pusat ke daerah (misal: kasus korupsi dalam Bansos, dana BOS dan DAK Pendidikan) tentunya perlu disiapkan mekanisme dan peraturan yang jelas untuk mencegah hal tersebut terjadi. Saat ini kelengkapan regulasi dalam pengelolaan dana desa ditenggarai masih minim. Selain UU No. 6 tahun 2014 tentang Desa, regulasi yang ada adalah PP No. 43 tahun 2014 tentang pelaksanaan UU Desa dan PP No. 60 tahun 2014 yang kemudian diubah dalam PP No. 22 tahun 2015 tentang Dana Desa yang Bersumber dari Anggaran Pendapatan dan Belanja Negara. Sementara itu masih banyak peraturan menteri hingga akhir Desember 2014 yang belum diterbitkan.

Dalam pengelolaan keuangan Desa, Pemerintah Desa mengacu pada Peraturan Menteri Dalam Negeri Nomor 113 Tahun 2014 tentang Pengelolaan Keuangan Desa. Keuangan Desa dikelola berdasarkan asasasas transparan, akuntabel, partisipatif serta dilakukan dengan tertib dan disiplin anggaran. Sejalan dengan itu Menteri Dalam Negeri membuat MOU dengan Kepala Badan Pengawasan Keuangan dan Pembangunan Nomor 900/6271/SJ dan Nomor MOU-16/x/D4/2015 tentang Peningkatan Pengelolaan Keuangan Desa. Maksud dan tujuan kerja sama ini untuk mendorong terwujudnya pengelolaan keuangan desa yang baik dan pemerintah desa yang bersih. Untuk mewujudkan tujuan tersebut BPKP mempunyai tugas dan tanggung jawab salah 
satunya yaitu melakukan pengembangan aplikasi pengelolaan keuangan desa. Hasil dari kerja sama itu adalah berupa Aplikasi Sistem Keuangan Desa (Siskeudes) yang digunakan oleh Pemerintah Desa dalam mengelola keuangan dana desa.

Aplikasi Sistem Keuangan Desa (Siskeudes) dimulai Tahun 2013 tentu menemukan banyak kendala yang dihadapi dalam penerapannya di Desa-desa. Mulai dari jumlah perangkat Desa yang minim, dan juga kualitas atau kemampuan dari Perangkat Desa itu sendiri dalam menjalankan aplikasi tersebut yang masih kurang memahami dengan baik. Banyak Desa yang sebenarnya belum siap menjalankan aplikasi tersebut tetapii harus dipaksa agar Desa dapat dengan mudah menatausahakan pendapatan dan belanja desa dengan baik, serta melaporkan pertanggungjawaban keuangan desa kepada walikota atau bupati dengan tepat waktu.

Penelitian yang membahas efektivitas pelatihan keuangan desa: upaya peningkatan profesionalisme aparatur desa yaitu Setyorini et al. (2017). Hasil penelitiannya menunjukkan pelatihan keuangan desa dapat meningkatkan pemahaman aparatur desa sehingga mampu memberikan pelayanan maksimal kepada masyarakat sehingga tercipta good village government. Hasniati (2016) mengembangkan sebuah model akuntabilitas pengelolaan dana desa yang dapat dijadikan sebagai rujukan oleh Pemerintah Desa agar penggunaan dana desa bisa dipertanggungjawabkan kepada seluruh pemangku kepentingan (stakeholder). Hasil penelitinnya menunjukkan akuntabilitas proses dalam pengelolaan dana desa adalah kesediaan dari para pengelola dana desa untuk menerima tanggung jawab atas apa yang ditugaskan kepadanya secara efisien, efektif, berkeadilan, dan dilaksanakan secara transparan dengan melibatkan masyarakat. Penelitian serupa telah dilakukan oleh Fajri (2015); Fauzi (2013); Khusniyatun dan Kiswanto (2017); Syaifullah (2017); dan Wahyuningsih dan Kiswanto (2016).
Penelitian Juwaini et al. (2018) bertujuan untuk memahami dan menganalisis proses administrasi keuangan desa menggunakan aplikasi SISKEUDES yang menyebabkan keterlambatan laporan dan mencari solusi terhadap kendala yang dihadapi dalam kegiatan administrasi keuangan desa menggunakan aplikasi SISKEUDES, dengan pen dekatan kualitatif. Hasil penelitian menunjukkan kegiatan administrasi yang mengakibatkan keterlambatan dalam laporan dalam penelitian ini adalah proses pembayaran pajak yang tidak dilakukan oleh bendahara karena perhitungan pajak menggunakan aplikasi SISKEUDES yang salah. Penelitian Amirruddin et al., (2012) ingin mengetahui transparansi dana di Desa Pertasi Kencana Kecamatan Kalaena Kabupaten Luwu Timur dan mengetahui maksimal kinerja dalam hal transparansi pengelolaan APBDesa. Hasil penelitiannya menunjukkan bahwa masyarakat belum merasakan transparansi pengelolaan APBDesa di Desa Pertasi Kencana Kecamatan Kalaena Kabupaten Luwu Timur karena masyarakat kurang dilibatkan dalam hal itu dan adapun transparansi isu terbukti kurang maksimal di karenakan kurang mudahnya diakses oleh masyarakat umum khususnya masyarakat desa di Desa Pertasi Kencana Kecamatan Kalaena Kabupaten Luwu. Hal ini disebabkan karena adanya masalah seperti tidak terbukanya pemerintah dan tidak mudahnya diakses sehingga masyarakat tidak mengetahui mengenai anggaran yang terpakai, selain itu trasparansi ini sering tidak terrealisasi sebagaimana mestinya kerena rendahnya pengaruh aparatur desa terhadap pengembangan dan pengelolaan alokasi dana desa ini menjadi faktor penghambat transparansi pengelolaan anggaran pendapatan dan belanja desa di Desa Pertasi Kencana Kecamatan Kalaena Kabupaten Luwu Timur padahal dari transparansi ini diharapkan dapat meningkatkan kreativitas, kesejahteraan dan kerja sama yang baik. Kajian Komisi Pemberantasan Korupsi (2015) menemukan 14 temuan pada empat aspek, yakni aspek regulasi dan 
kelembagaan; aspek tata laksana; aspek pengawasan; dan aspek sumber daya manusia.

Penelitian yang membahas keuangan desa pernah dilakukan di China oleh Wang (2013); Meng (2013); Xiao (2015); Yi (2014); dan Zhang dan Wang (2017). Hasil penelitian Wang (2013) menunjukkan rendahnya kualitas personil akuntansi secara keseluruhan, sistem keuangan tidak dieksekusi dengan ketat, pengungkapan keuangan yang gagal untuk memainkan perannya, kegagalan pengawasan keuangan, dan tidak adanya audit keuangan tingkat desa. Yi (2014) menganalisis bahwa dari tiga model pengelolaan keuangan tingkat desa yang ada yaitu "keuangan desa yang dikelola oleh desa", "keuangan desa yang dikelola oleh kota", dan "akuntansi desa dikelola oleh agen" sedangkan Meng (2013); Xiao (2015); dan Zhang dan Wang (2017) menyimpulkan bahwa beberapa masalah yang ada di desa seperti akuntan yang kurang profesional, akuntansi dan manajemen aset tidak standar.

Penelitian terkait dengan keuangan desa dilakukan juga oleh peneliti lain diantaranya Bustamam et al. (2018); Simangunsong dan Wicaksono (2017); Suwandi (2015); dan Nurhakim dan Yudianto (2018). Keempat penelitian ini membahas pengelolaan keuangan desa terkait dengan alokasi dana desa dan dana desa.

Penelitian ini mengambil lokasi penelitian di Kabupaten Nganjuk. Pemerintah Kabupaten Nganjuk mulai tahun 2015 menggunakan Aplikasi Sistem Pengelolaan Keuangan Desa (SILOKDES). Aplikasi ini dibuat oleh swasta dan sudah diimplementasikan di Kabupaten Nganjuk mulai tahun 2015, namun karena ada kewajiban untuk mengimplementasikan Sistem Keuangan Desa (Siskeudes) mulai tahun 2017 sesuai dengan edaran KPK Nomor B.7508/0116/08/2016 yang menyatakan bahwa semua Kepala Desa harus memahami dengan baik dan menggunakan Aplikasi Sistem Keuangan Desa (Siskeudes) yang dikembangkan oleh Badan Pengawasan Keuangan dan
Pembangunan (BPKP) bekerjasama dengan Kementerian Dalam Negeri (Kemendagri) untuk pengelolaan Keuangan Desa.

Berdasarkan uraian yang telah dijelaskan sebelumnya, maka penulis tertarik untuk mengangkat sebuah topik penelitian dengan judul Strategi Implementasi Aplikasi Sistem Keuangan Desa: Studi Kasus Pemerintah Daerah Kabupaten Nganjuk. Pemerintah Daerah Kabupaten Nganjuk ini sangat unik karena semua operator desa sudah terlatih menggunakan aplikasi. Adapun rumusan masalah penelitian ini adalah bagaimana pelaksanaan workshop pengelolaan keuangan desa tahap I dan workshop dan pendampingan pengelolaan keuangan desa tahap II Kabupaten Nganjuk? Bagaimana dampak workshop terhadap pengelolaan keuangan desa Kabupaten Nganjuk? bagaimanakah problematika pengelolaan keuangan desa Kabupaten Nganjuk (aspek positif dan negatif)?

\section{TINJAUAN TEORETIS}

\section{Pembangunan Desa dalam Perspektif Undang-Undang No. 6 Tahun 2014 Tentang Desa}

Kelahiran UU Desa dilatarbelakangi pertimbangan bahwa pengaturan tentang desa yang selama ini berlaku sudah tidak sesuai lagi dengan perkembangan kedudukan masyarakat, demokratisasi serta upaya pemerintah dalam mendorong kemajuan dan pemerataan pembangunan. Selain itu, UU Desa sekaligus merupakan penegasan bahwa desa memiliki hak asal usul dan hak tradisional dalam mengatur dan mengurus kepentingan masyarakat setempat.

UU Desa membawa misi utama bahwa negara wajib melindungi dan memberdayakan desa agar menjadi kuat, maju, mandiri dan demokratis sehingga dapat menciptakan landasan yang kuat dalam melaksanakan pemerintahan. Dengan demikian pembangunan desa diharapkan dapat meningkatkan kesejahteraan masyarakat dan kualitas hidup manusia Indonesia. Pembangunan desa akan berdampak positif bagi upaya penanggulangan kemiskinan 
melalui penyediaan pemenuhan kebutuhan dasar masyarakat, pembangunan sarana dan prasarana, pengembangan potensi ekonomi lokal dan pemanfaatan sumberdaya alam dan lingkungan secara berkelanjutan2. Berdasarkan azas rekognisi dan subsidiaritas, UU Desa membawa perubahan pokok antara lain: 2 Pasal 87 Undang-Undang Desa a). Desa memiliki identitas yang mandiri sebagai self-governing community dalam tata pemerintahan di Indonesia dimana pemerintahan desa dipilih secara demokratis dan akuntabel oleh masyarakat, b). Desa menyelenggarakan pembangunannya secara partisipatif dimana desa menyusun perencanaan, prioritas belanja dan melaksanakan anggaran secara mandiri termasuk mengelola anggaran yang didapatkan secara langsung serta mendaftarkan dan mengelola aset untuk kesejahteraan masyarakat termasuk mendirikan BUMDesa, dan c). Desa memiliki wewenang untuk bekerjasama dengan desa lain untuk peningkatan pelayanan dan kegiatan ekonomi.

UU Desa secara khusus meletakkan dasar bagi perubahan tata kelola desa yang dibangun di atas prinsip keseimbangan antara lembaga (check and balance), demokrasi perwakilan dan permusyawaratan serta proses pengambilan keputusan secara partisipatif melalui musyawarah desa sebagai forum pengambil keputusan tertinggi dalam perencanaan, pelaksanaan, pengawasan dan pertanggungjawaban pembangunan desa.

Dengan melibatkan partisipasi berbagai kelompok kepentingan di masyarakat, Kepala Desa dan Badan Permusyawaratan Desa (BPD) menyelenggarakan musyawarah desa sebagai forum pengambil keputusan tertinggi untuk menetapkan Rencana Pembangunan Jangka Menengah (RPJM) Desa dan Rencana Tahunan Desa, pengelolaan aset dan BUMDesa serta keputusan-keputusan strategis lainnya.

\section{Pembiayaan Pembangunan Desa}

Pembiayaan pembangunan desa berasal dari keuangan desa yang diperoleh dari beberapa sumber yaitu: pendapatan asli desa, alokasi APBN, bagian dari hasil pajak daerah dan retribusi daerah kabupaten atau kota, bantuan keuangan dari APBD provinsi dan kabupaten atau kota, hibah dan sumbangan yang tidak mengikat dan pendapatan desa lain yang sah

Pengelolaan keuangan desa pada dasarnya mengikuti pola pengelolaan keuangan daerah dimana Kepala Desa merupakan pemegang kekuasaan pengelolaan keuangan desa. Pendapatan, belanja dan pembiayaan desa harus ditetapkan dalam Anggaran Pendapatan dan Belanja (APB) Desa yang ditetapkan dalam peraturan desa oleh Kepala Desa bersama Badan Permusyawaratan Desa (BPD). Pertanggungjawaban terhadap penggunaan dan pengelolaan keuangan desa ini merupakan tanggungjawab Kepala Desa untuk disampaikan kepada: a) Bupati atau Walikota pada setiap akhir tahun anggaran yang disampaikan melalui camat, b). Badan Permusyawaratan Desa pada setiap akhir tahun anggaran, dan c). Masyarakat dalam musyawarah desa.

Berdasarkan UU Desa terdapat 4 (empat) sumber pembiayaan yang dikelola oleh kas desa yakni sumber pembiayaan dari Pusat, sumber pembiayaan dari Daerah baik Kabupaten maupun Provinsi; sumber pembiayaan yang berasal dari usaha desa dan sumber pembiayaan lainnya.

\section{Siklus Pembangunan Desa}

Dalam pelaksanaan pembangunan desa harus menerapkan prinsip-prinsip transparansi serta pelibatan partisipasi masyarakat baik dalam perencanaan, pelaksanaan maupun dalam pengawasan dan pemantauan. Dalam kerangka UU Desa, siklus pembangunan desa mencakup 3 (tiga) tahap penting yaitu perencanaan, pelaksanaan dan pertanggungjawaban. RAN HASIL KAJIAN PENELOLAN KEUNGAN Pengawasan Pembangunan Desa

UU Desa meletakkan prinsip dasar untuk peneyelenggaraan pengawasan dan pemantauan pembangunan desa yang meliputi pengawasan oleh supra-desa (down- 
ward accountability), pengawasan oleh lembaga desa dan pengawasan dari masyarakat (upward accountability). Terdapat beberapa mekanisme pengawasan dan pemantuan sebagai berikut: a) Pengawasan oleh supra desa secara berjenjang oleh Pemerintah Kabupaten atau Kota dan oleh Pemerintah Pusat dalam hal ini Kementerian Dalam Negeri, Kementerian Desa dan Kementerian Keuangan (pasal 26 PP No. 60 tahun 2014). Dalam operasionalnya, pengawasan oleh Pemerintah kabupaten atau kota menjadi tanggung jawab Bupati atau Walikota. Fungsi pengawasan tersebut didelegasikan oleh Bupati atau Kota kepada camat dan juga Inspektorat Kabupaten atau Kota. Hasil pengawasan Pemerintah Kabupaten atau Kota disampaikan kepada Pemerintah Pusat terkait dengan unsur pengawasannya. Pengawasan dana desa disampaikan kepada Kementerian Keuangan, pengawasan pembangunan desa disampaikan kepada Kementerian Desa dan pengawasan pemerintahan disampaikan kepada Kementerian Dalam Negeri, b) Pengawasan supra desa lainnya adalah pengawasan dari Badan Pemeriksa Keuangan (BPK) dan Badan Pengawasan Keuangan dan Pembangunan (BPKP). Hal ini didasari oleh UU No. 15 tahun 2004 tentang Pemeriksaan Pengelolaan dan Tanggung Jawab Keuangan Negara dimana keuangan desa yang berasal dari Pemerintah Pusat dan Pemerintah Daerah termasuk kedalam kategori Keuangan Negara karena sumbernya APBN dan APBD. PP No. 60 tahun 2008 tentang Sistem Pengendalian Intern Pemerintah juga memberikan kewenangan bagi BPKP untuk mengawasi pengelolaan keuangan desa karena sumbernya yang berasal dari APBN maupun APBD, c) Pengawasan oleh lembaga BPD sebagai bagian dari fungsi pengawasan terhadap kinerja Kepala Desa antara lain melalui tanggapan atas pertanggungjawaban Kepala Desa dan pengaduan masyarakat yang disampaikan melalui BPD (pasal 55 dan 82 UU Desa). Seperti halnya fungsi DPR dan DPRD, BPD juga memiliki fungsi pengawasan terhadap perangkat desa dalam mengelola keuangan desa, d) Pengawasan oleh masyarakat yang dijamin haknya untuk memantau dan menanggapi laporan pertanggungjawaban Kepala Desa (pasal 82 UU Desa). Pengawasan masyarakat kepada perangkat desa dalam mengelola keuangan desa didukung dengan kewajiban bagi desa untuk memiliki Sistem Informasi Desa sebagai pelaksanaan ketentuan hak masyarakat untuk mendapatkan informasi (pasal 26, 55, 82 UU Desa).

Selanjutnya UU Desa mengamanatkan pembentukan peraturan yang lebih terperinci mengenai tata cara pelaksanaannya melalui Peraturan Pemerintah dan Peraturan di tingkat Menteri termasuk menyangkut sanksi jika terjadi pelanggaran atau pelaksanaan yang tidak sejalan dengan prinsip dan tujuan pembangunan desa.

Khusus pengelolaan dana desa, dalam PP No. 22 tahun 2015, disebutkan adanya sanksi bagi daerah dan desa yang tidak mengelola dana desa dengan baik. Kriteria yang digunakan adalah: a). Adanya SiLPA (Sisa Lebih Perhitungan Anggaran) dari APBDesa lebih dari 30\% di akhir tahun anggaran. Sanksi yang diterapkan adalah sanksi administratif berupa penundaan pencairan dana desa tahap berikutnya oleh Menteri Keuangan dan atau pemotongan dana desa tahun berikutnya, b) Jika Bupati atau Walikota tidak segera meyalurkan dana desa ke rekening desa (lebih dari 15 hari) setelah desa memenuhi kewajibannya, Menteri Keuangan dapat melakukan penundaan penyaluran Dana Alokasi Umum dan Dana Bagi Hasil yang menjadi hak Kabupaten atau Kota bersangkutan.

\section{Kelembagaan Pembangunan dan Pembina- an Desa}

Dengan dilantiknya Presiden Ir. H. Joko Widodo dan Drs. Muhammad Jusuf Kalla di hadapan majelis Permusyawaratan Rakyat pada 20 Oktober 2014, Presiden mulai memutuskan pembentukan kabinet yang dikenal dengan kabinet kerja melalui Keputusan Presiden Republik Indonesia Nomor 121/P Tahun 2014 Tentang Pembentukan 
Kementerian dan Pengangkatan Menteri Kabinet Kerja Periode Tahun 2014-2019. Dalam kabinet kerja tersebut, terdapat sejumlah perubahan terhadap organisasi dan tata kerja sejumlah kementerian, yang lebih lanjut diatur dalam Peraturan Presiden (Perpres) No. 165 tahun 2014 tentang penataan tugas dan fungsi kabinet kerja. Dalam Perpres No. 165 tahun 2014 terdapat perubahan tugas dan fungsi kementerian yang terkait dengan pembinaan desa dan kawasan perdesaan. Dalam pasal 6 huruf (a) Perpres No. 165 tahun 2014 menyebutkan bahwa "Dalam hal organisasi dan tata kerja Kementerian Desa, Pembangunan Daerah Tertinggal dan Transmigrasi sebagaimana dimaksud dalam Pasal 1 ayat (1) angka 26 belum terbentuk maka Menteri Desa, Pembangunan Daerah Tertinggal, dan Transmigrasi memimpin dan mengkoordinasikan: (a) Penyelenggaraan tugas dan fungsi di bidang desa yang meliputi kelembagaan dan pelatihan masyarakat desa, pemberdayaan adat dan sosial budaya masyarakat desa, usaha ekonomi masyarakat desa, dan sumber daya alam dan teknologi tepat guna perdesaan yang dilaksanakan oleh Kementerian Dalam Negeri".

Dalam pasal 6 butir (a) Perpres No. 165 tahun 2014 tersebut terlihat adanya perubahan tugas dan fungsi di bidang desa, yang awalnya dilaksanakan oleh Kementerian Dalam Negeri menjadi tugas Kementerian Desa.

Kementerian Dalam Negeri mempunyai tugas menyelenggarakan urusan di bidang pemerintahan dalam negeri untuk membantu Presiden dalam menyelenggarakan pemerintahan negara4. Sedangkan Kementerian Desa PDTT mempunyai tugas menyelenggarakan urusan pemerintahan di bidang pembangunan desa dan kawasan perdesaan, pemberdayaan masyarakat desa, percepatan pembangunan daerah tertinggal, dan transmigrasi untuk membantu Presiden dalam menyelenggarakan pemerintahan negara5. Sebagai bagian dari tindak lanjut Perpres No. 165 tahun 2014, Presiden mengeluarkan Perpres No. 11 tahun 2015 ten- tang Kementerian Dalam Negeri dan Perpres No. 12 tahun 2015 tentang Kementerian Desa, Pembangunan Daerah Tertinggal dan Transmigrasi. Diharapkan dengan adanya Perpres 11/2015 dan Perpres 12/2015 mampu mempertegas tugas dan fungsi masing-masing Kementerian, terutama yang terkait dengan Pembangunan dan Pembinaan desa.

\section{METODE PENELITIAN \\ Ruang Lingkup}

Objek dari penelitian ini adalah Dinas Pemberdayaan Masyarakat dan Desa $(P M D)$ dan Pemerintah Desa Kabupaten Nganjuk dengan fokus pada strategi implementasi sistem keuangan desa sebagai implementasi dari diterapkannya UU No. 6 tahun 2014 tentang Desa.

Pemenuhan data primer untuk strategi implementasi sistem keuangan desa didapatkan dari hasil wawancara dengan informan yang direncanakan sebagai berikut:

Tabel 1

Daftar Informan Penelitian

\begin{tabular}{cl}
\hline \hline No & \multicolumn{1}{c}{ Jabatan } \\
\hline 1 & Sekda Kabupaten Nganjuk \\
2 & Asisten 1 Kabupaten Nganjuk \\
3 & Kepala Dinas PMD Kabupaten \\
& Nganjuk \\
4 & Kasi Pemerintahan Kabupaten \\
& Nganjuk \\
5 & Staf PMD Kabupaten Nganjuk \\
6 & Operator Desa \\
7 & Pendamping Ahli \\
8 & Pendamping Desa \\
9 & Pendamping Lokal Desa \\
\hline
\end{tabular}

\section{Metodologi Penelitian}

Metodologi penelitian yang dilakukan adalah: 1) Melakukan wawancara dan analisis terhadap apa saja kebutuhan pengguna (operator desa) terkait informasi siskeudes, 2) Melakukan wawancara dan analisis terhadap kelebihan dan kekurangan Silokdes dan Siskeudes, 3) Merumuskan strategi Pe- 
merintah Daerah Nganjuk untuk mengimplementasikan Aplikasi Sistem Keuangan Desa, 4) Mengidentifikasi apa saja kendala Pemerintah Daerah Nganjuk untuk mengimplementasikan Aplikasi Sistem Keuangan Desa, 5) Pelaporan, 6) Melakukan Focus Group Discussion dengan narasumber terkait untuk memperkaya analisis, riviu hasil kajian dan membantu dalam pe- rumusan rekomendasi.

\section{ANALISIS DAN PEMBAHASAN}

Strategi implementasi aplikasi sistem keuangan desa pada pemerintah daerah kabupaten Nganjuk beberapa tahap, 1) workshop pengelolaan keuangan desa tahap 1 , workshop dan pendampingan pengelolaan keuangan desa II, 3. Identifikasi problematika pengelolaan keuangan desa Kabupaten Nganjuk

\section{Tahap Awal Workshop Pengelolaan Keua- ngan Desa}

Workshop Pengelolaan Keuangan Desa dengan aplikasi siskeudes ini diarahkan agar peserta (operator desa) meningkatkan kemampuan untuk menjadi operator aplikasi keuangan desa (SISKEUDES) yang handal pada desanya masing-masing sehingga mampu menginput data perencanaan, penganggaran, pelaporan dan pertanggungjawaban keuangan desa. Workshop diselenggarakan selama 5 hari dengan materi, dan metode sebagai berikut:

Tabel 2

Metodologi Workshop

\begin{tabular}{ccc}
\hline \hline Hari & \multicolumn{1}{c}{ Materi } & Metode \\
\hline 1 & $\begin{array}{l}\text { Pembekalan dan insta- } \\
\text { lasi siskeudes }\end{array}$ & Praktek \\
2 & $\begin{array}{l}\text { a. Buku Kerja Visi, } \\
\text { misi, tujuan, sasar- }\end{array}$ & Peori dan \\
& Praktek \\
& b. Buku RPJM Kerja Peng- \\
& anggaran dan Be- \\
& lanja (Kabupaten
\end{tabular}

Simulasi Kecamatan Mambi, Pemerintah Desa Rantebulahan)

a. Visi, misi, tujuan, sasaran, dan RPJM Desa masing-masing peserta

b. Penganggaran dan Belanja Pemerintah Desa masing-masing peserta

Buku kerja penatausahaan, pelaporan dan pertanggungjawaban (Kabupaten simulasi Kecamatan Mambi, Pemerintah Desa Rantebulahan)

5 Penatausahaan, pelaporan dan pertanggungjawaban Pemerintah Desa masingmasing peserta Teori dan
Praktek Teori dan
Praktek

Praktek Praktek

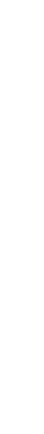

Workshop ini bertempat di Istana Hotel \& Restaurant Jl. Raya Madiun Km 2 Bagor Kelurahan atau Desa Kedondong Kec. Bagor Kab. Nganjuk, 64461 Nomor Telepon: 0358 323572 berlangsung selama 4 (empat) hari untuk angkatan pertama yang telah dilaksanakan pada pada hari Selasa-Sabtu tanggal 12-16 September 2017 dan 4 (empat) hari untuk angkatan kedua yang telah dilaksanakan pada pada hari Sabtu-Rabu tanggal 16-20 September 2017.

Hasil wawancara dengan Sekda Kabupaten Jombang sebagai berikut: "Ah, makanya kan tadi kami sampaikan. Jadi tugas-tugas para operator untuk panjenengan dari. Mulai konsep sisi mulai perencanaan. Mulai dari ya itu kan e sampe pelaksanaannya. Trus penatausahaan keuangannya. Pelaporan pertanggungjawaban. Pelaporannya pertanggungjawabannya. La minimal mereka-mereka itu apa yang sudah 
bisa di dapat untuk berkontribusi terhadap desanya itu kan yo luar biasa seneng to. Apapun kalau memang dia sudah, dari sisi itu kan e semakin berhasil dari nilai pem bangunan. Dan dengan akuntabelnya itu tadi. Telah berdampak terhadap e penyelewengannya kan. Lebih kecil".

Secara keseluruhan pelaksanaan program dan realisasi penggunaan workshop berjalan dengan baik, namun demikian masih ada beberapa masalah diantaranya: 1) pada putaran 1 adanya referensi kegiatan yang menggunakan silokdes versi 2 , padahal seharusnya menggunakan versi 3 , sehingga harus ada update referensi kegiatan dan rekening APBDes, 2) Lokasi Workshop tidak ada AC sehingga penceramah, staf pendukung dan peserta kepanasan. Ruang pelatihan kurang proporsional dengan program pelatihan, panas dan terlalu luas. Seyogyanya tempat pelatihan suasana dan kondisi ruang ber AC dan proporsional sehingga capaian target modul bisa terpenuhi, 3) Beberapa peserta belum membawa bukti transaksi sehingga sulit mengikuti workshop, 4) Beberapa peserta pelatihan khususnya dari pendamping desa kurang aktif mengikuti proses pelatihan, banyak yang semaunya sendiri dalam mengerjakan modul pelatihan. Seyogyanya melihat keseriusan non pendamping desa tidak perlu dicampur, karena bisa mempengaruhi peserta lainnya, 5) Peserta memiliki semangat untuk belajar namun masih memiliki cara pandang sistem keuangan lama yang dianggap memiliki banyak kelebihan dibandingkan siskeudes, seyogyanya perlu ada ruang dan waktu untuk memberikan arah perubahan mindset terlebih dulu, khususnya sisi politik, sisi akuntabilitas dan sisi kepentingan individu, 6) SDM peserta pelatihan yang baik tentang penggunaan sistem komputer maupun aplikasinya perlu ditindak lanjuti dengan pelatihan kembali sebagai upaya kesinambungan dan menjaga marwah spirit memahami siskeudes secara benar dan tepat, 7. Adanya pergantian peserta operator desa pada hari kedua. Hal ini membuat situasi menjadi tidak kondusif.

\section{Workshop dan Pendampingan Pengelolaan keuangan Desa Tahap II}

Workshop dan pendampingan pengelolaan keuangan desa tahap II ini diarahkan agar peserta meningkatkan kemampuan operator sistem keuangan desa (SISKEUDES), pendamping lokal, pendamping desa dan pendamping ahli, sehingga mampu mengimplementasikan SISKEUDES berdasarkan data pengelolaan desa masingmasing desa, menyelesaikan problem apa saja yang belum tercover pada workshop pengelolaan keuangan desa tahap I.

Workshop dan pendampingan pengelolaan keuangan desa tahap II diselenggarakan selama 2 hari dengan materi, dan metode sebagai berikut pada Tabel 3 .

Workshop dan pendampingan ini bertempat di Aula wisma koperasi Jl. Raya Madiun Km 2 Bagor Kelurahana atau Desa Kedondong Kec. Bagor Kab. Nganjuk, 64461 berlangsung selama 2 (dua) hari untuk masing-masing angkatan dan berlangsung selama 6 (enam) hari.

Tabel 3

Metodologi Refreshment (Training of Trainer II)

\begin{tabular}{clc}
\hline \hline Hari & \multicolumn{1}{c}{ Materi } & Metode \\
\hline Hari 1 & 1. & Review Workshop \\
& Pengelolan & Teori dan \\
& Keuangan Desa & Praktek \\
& Manual \\
& 2. Penjelasan & \\
& Perbedaan SPP & \\
& Panjar dan SPP & \\
& Definitif & \\
& 3. Penjelasan & \\
& Pemberian & \\
& Penomoran Bukti & \\
& Transaksi & \\
4. & Pendampingan \\
& Siskeudes \\
\hline
\end{tabular}




\begin{tabular}{|c|c|c|}
\hline Hari 2 & $\begin{array}{l}\text { 1. Penjelasan } \\
\text { Perubahan } \\
\text { Anggaran (PAK) } \\
\text { 2. SiLPA dan } \\
\text { Penggunaannya } \\
\text { 3. Penyusunan } \\
\text { Laporan Kekayaan } \\
\text { Milik Desa } \\
\text { (LKMD) } \\
\text { 4. Database } \\
\text { Siskeudes } 2018 \\
\text { 5. Pendampingan } \\
\text { Siskeudes }\end{array}$ & $\begin{array}{c}\text { Teori dan } \\
\text { Praktek } \\
\text { Manual }\end{array}$ \\
\hline
\end{tabular}

Masing-masing angkatan terdiri dari 100 peserta yang terdiri dari operator desa (yang ikut pada workshop tahap I), pendamping lokal, pendamping desa dan pendamping ahli. Workshop dan pendamping ini berlangsung 20-25 November 2017.

Secara keseluruhan pelaksanaan program dan realisasi penggunaan workshop dan pendampingan tahap II berjalan dengan baik, namun demikian masih ada beberapa masalah diantaranya: 1). materi yang diajarkan yaitu SiLPA dan Penggunaannya dan Penyusunan Laporan Kekayaan Milik Desa (LKMD) belum pernah dipraktekan, 2). Operator desa banyak yang menganggarkan dalam bentuk gelondongan (tidak rinci), 3). Operator desa masih menggunakan Dual sistem yaitu SILOKDES dan SISKEUDES karena workshop diselenggarakan pada akhir tahun. Software SILOKDES tersebut disediakan dari pihak Dinas Pemberdayaan dan Masyarakat Desa Kabupaten Nganjuk (PMD) dengan bekerjasama dengan pihak swasta. Program atau aplikasi ini dibeli oleh Pihak PMD dengan menggunakan sumber dana dari anggaran PMD sendiri, 4. Perbedaan mekanisme pencairan dana dari rekening desa ke kas di bendahara. Hasil wawancara dengan Kepala Dinas PMD terkait dengan gelondongan RAB sebagai berikut: "Betul tadi ada contoh begini Pak, ada. Ada peserta nanya tadi Bu. Pak, RAB kami hanya gelondongan Pak, misalnya gitu yo. Gelondongan itu maksudnya begini Pak, bangun jalan raya. Misalnya, eh uh sorry, bangun jalan kam..pav..paving kampung gitu ya, 50 juta wes ngunu tok maksude bunyinya. Itu dibuat apa?. Itu nggak di perinci untuk belanja apa".

"Tapi kalo bapak melakukan itu, itu berarti berusaha untuk menyembunyikan rencana. Loh iya. Itu menyembunyikan rencana. Artinya bapak tidak punya perencanaan yang baik. Iya Kan gitu to Pak ahhh saya tidak mengatakan salah Pak. Itu perencanaannya kurang baik.. Ada duit 50 juta dipake buat apa ndak tau, loh berarti kan tidak punya perencanaan yang baik. Nah sekarang tiba-tiba nggak dipake untuk itu, nanti juga nggak ketahuan juga wong beli semen berapa nggak tau. Wong gelondongan. Apa-apanya nggak tau kan gitu to. Lo Pak tapi kan gini to Pak, faktanya nanti kan bisa lebih rendah daripada standard, oya boleh, standardnya bayar pegawai maksimal 80. Bapak bayari pegawai 60. Ya nggak papa di RABnya 60 nggak harus 80 wong kebutuhannya 60 kok. Oh gitu ya pak, lah iya hahaha. La ya to pak he'e. Standard itu kan standard tinggi ya kan mungkin ada kota di kecamatan yang pegawainya dibayar mahal kan gitu. Tapi ada desa juga yang jauh yang. Iya. Wong ini duit negara kan harus di pertanggungjawabkan kan prinsipnya begitu. Itu yang kita coba sebenarnya e informasikan ke mereka"

\section{Dampak Workshop Terhadap Pengelolaan Keuangan Desa}

Hasil kompilasi siskeudes pada Workshop pengelolaan keuangan desa I menunjukkan bahwa dari 264 Desa yang mengikuti Workshop ini terdapat 226 $(85,60 \%)$ yang sudah menyelesaikan Penganggaran, sisanya $14,40 \%$ ada yang belum selesai, bermasalah dengan database dan belum mengumpulkan, dan hanya sekitar $6 \%$ peserta yang sudah menginput penatausahaan. Namun Workshop ini paling tidak sudah meletakkan dasar untuk penatausahaan, disamping memang karena dana (Dana Desa tahap 2 dan ADD tahap 2, serta dana lain) yang masih belum cair. Di- 
samping itu masih banyak yang menyusun RAB secara gelondongan, APB Desa tidak disusun dengan lebih terinci.

Oleh karena itu Dinas PMD Nganjuk dengan menggunakan Dana PAK Kabupaten Nganjuk melakukan Workshop dan Pendampingan pengelolaan keuangan desa II yang menyediakan fasilitas pendampingan, konsultasi dan mereview kembali materi yang belum jelas pada workshop pengelolaan keuangan desa I.

Workshop Pengelolaan Keuangan desa II ini sebagai ajang untuk menyamakan persepsi terkait dengan peraturan bupati dengan permendagri dan Modul Pengelolaan Keuangan Desa 2016 yang diterbitkan oleh BPKP.

Salah satu problem yang sering ditanyakan adalah SPP (surat permintaan pembayaran). Menurut pedoman keuangan desa oleh BPKP surat permintaan pembayaran adalah yang mengajukan SPP adalah panitia pelaksana kepada kepala Desa dan sekretaris desa melakukan veryfikasi, namun pada kenyataanya berdasarkan system SILOKDES dan Peraturan Bupati Nganjuk Nomor 11 Tahun 2015 Tentang Pengelolaan Keuangan Desa, SPP harus diajukan ke Camat dengan disertasi dengan RAB sebagai dasar pencairan dana.

Problem kedua yaitu adanya perbedaan software antara SILOKDES dan SISKEUDES. Diantaranya: 1 . SILOKDES bisa menampilkan $\mathrm{RAB}$ dengan lebih rinci untuk semua aktifitas sedangkan SISKEUDES hanya RAB belanja modal, 2. judul kegiatan dengan software SISKEUDES panjangnya dibatasi, 3 . pengalokasian anggaran dengan SILOKDES lebih mudah karena operator desa mengetahui berapa sisa anggaran yang belum digunakan

Problem ketiga, instalasi software SISKEUDES yang memerlukan asumsi dan mekanisme uang unik, diantaranya office acces harus sempurna dan MAC tidak support, sehingga banyak operator desa yang tidak bisa membuka SISKEUDES ketika instalasi tidak sempurna.
Keempat, problem penomoran bukti transaksi yang sudah terlanjur jadi. Pada saat workshop operator desa sudah melaksanakan pelaporan dan pertanggungjawaban keuangan dengan dengan menggunakan SILOKDES, sehingga operator desa menggunakan data historis ketika melakukan penatausahaan keuangan desa

Kelima, workshop pengelolaan keuangan desa dilaksanakan pada akhir tahun yaitu bulan September, idealnya kegiatan seperti ini dilaksanakan pada awal tahun sekalian operator desa menyusun APB Desa. Pada saat Workshop Pertanggungjawaban APB Desa terutama terkait dengan ADD tahap I dan Dana Desa tahap I sudah selesai.

Keenam, Kabupaten Nganjuk pada tahun 2017 masih menggunakan software SILOKDES untuk penganggaran, pelaksanaan, pelaporan maupun pertanggungjawaban keuangan desa. Penggunaan SISKEUDES secara resmi akan dilakukan sejak penyusunan APB Desa 2018. Hal ini menjadikan operator desa sedikit malas karena harus menggunakan 2 (dua) software secara bersamaan sekaligus.

Ketujuh, data penatausahaan, pelaksanaan, pelaporan dan pertanggungjawaban keuangan desa sebagian besar ada di bendahara dan kepala desa. Operator desa kesulit an untuk melakukan penatausahaan keuangan desa terutama terkait dengan aspek perpajakan, yaitu PPh 21, PPh 22, PPh 23.

\section{Problematika Pengelolaan Keuangan Desa Kabupaten Nganjuk}

Problematika pengelolaan keuangan desa kabupaten nganjuk meliputi:

\section{Sinergi Antara Camat, Dinas PMD, Biro Hukum dan Inspektorat}

Sinergi adalah membangun dan memastikan hubungan kerjasama yang produktif serta kemitraan yang harmonis dengan para pemangku kepentingan, untuk menghasilkan karya yang bermanfaat dan berkualitas. Tujuan Sinergi adalah mempengaruhi perilaku orang secara individu maupun kelompok untuk saling berhubu- 
ngan, melalui dialog dengan semua golongan, dimana persepsi, sikap dan opininya penting terhadap suatu kesuksesan. Menurut Deardorff dan Williams (2006) sinergi adalah sebuah proses dimana interaksi dari dua atau lebih agen atau kekuatan akan menghasilkan pengaruh gabungan yang lebih besar dibandingkan jumlah dari pengaruh mereka secara individual. Dengan demikian, terdapat 2 suatu sinergi apabila hasil dari gabungan misalnya dua kekuatan akan menghasilkan persamaan matematik sebagai berikut: $1+1>2$.

Manusia adalah makhluk sosial yang tidak dapat hidup sendiri. Untuk dapat bertahan hidup maka manusia harus berinteraksi dan berhubungan dengan orang lain. Hubungan antar manusia ini merupakan bentuk sinergi yang bersifat eksternal yang penting untuk dapat menjamin keberlangsungan hidup manusia karena tidak ada satupun manusia yang dapat memenuhi semua kebutuhan hidupnya sendirian saja. Pada tingkatan organisasi maka sinergi sangat dibutuhkan oleh suatu organisasi agar pelaksanaan tugas dan fungsi organisasi tersebut dapat berjalan dengan baik dan sempurna (well and excellent). Sebagaimana manusia, sinergi yang dibutuhkan oleh suatu organisasi adalah sinergi yang bersifat internal dan eksternal.

Sinergi internal adalah sinergi antara organ-organ yang ada di dalam organisasi tersebut yang memungkinkan seluruh organ organisasi tersebut dapat bergerak seiring dan sejalan. Sama seperti manusia, suatu organisasi tidak dapat hidup sendiri. Suatu organisasi akan berinteraksi dengan lingkungan eksternal. Sinergi dengan lingkungan eksternal ini sangat dibutuhkan oleh suatu organisasi agar dapat mencapai tujuan dari organisasi tersebut. Tugas camat sesuai dengan Peraturan Bupati Nganjuk Nomor 11 Tahun 2015 pasal 24 dan 28 mempunyai Kewenangan melakukan Evaluasi Rancangan Peraturan Desa Tentang APB Desa, pada pasal 34 Camat meneliti surat permohonan Surat Permohonan Penyaluran Dana Transfer Desa, pada pasal 40 Camat membuat
Surat Pengantar Pencairan Dana dan pada pasal 46 Camat melakukan pembinaan dan pengawasan desa yaitu memeriksa buku penatausahaan dan laporan pertanggungjawaban keuangan desa.

Hasil wawancara dengan pak Bambang dari Desa Sawahan terkait dengan tugas Camat dalam pencairan dana: "Harusnya duit masuk ke rekening Desa 100\% bisa digunakan oleh Desa Pak. Lo yaopo Pak wong RAB e sudah sampean setujui og Pak. Halo Pak, saya ulangi lagi ya Pak. Kita ini awal tahun Pak, saya mau rencanakan kegiatan saya selama satu tahun. Bapak setuju ndak? Begitu dana itu cair ya saya kan saya gunakan untuk perencanaan saya, ngapain dihalangi untuk melaksanakan perencanaan yang sudah bapak setujui? Kan sudah setuju to. Gimana coba? Hayoo, coba Bapak rasakan. Nah. Kalau mau mau berdebat, mau gerilya, di depan tadi, Bapak obrak-abrik. Hee iki RAB ngawur, iki elek, ayo ganti-ganti! Opo! rencana kok sak penak e dewe. Gak isok iki. Yo obrak-abrik en nek ngarep, ojo lek dana wes cair trus sampean haling-halangi untuk melaksanakan. Itu namanya perencanaan yang buruk! Gitu. Makanya ketika RAB dikunci menjadi APBDes. Dia nggak bisa ngotak-atik lagi. Dan itu sudah persetujuan, kan gitu to? kedua belah pihak dengan sengaja, maksudnya begitu, dengan sengaja, maka begitu dana cair ya silahkan kalau Perbup nya menambahkan bahwa verifikasinya lewat Camat misalnya, itu hanya formalitas. Lo iya dong! Wong sudah disetujui kok diawal. Artinya tugas camat untuk meyakinkan bahwa yang akan dia lakukan, kan panitia pelaksana nih mau melaksanakan dia harus bikin RAB lagi to ahh sudah sesuai dengan eee APBDesnya. Udah itu saja. Nggak sesuai suruh ngembalikan. Kan ngono seh ahhh. Ya disitu fungsinya. Bukan fungsi menghalanghalangi uang untuk di ambil, atau mohon maaf mungkin pajak dan seterusnya malahan. Nggak ada fungsi itu. Gawat kalau desa digitukan. Pengawasan silahkan. Setelah uang digunakan nggak dibelanjakan, bapak boleh panggil, kan pengawasan. Saya sangat 
paham soal itu. Bapak boleh ambil. Kan lain cerita. Kan setelah dilaksanakan di evaluasi, lo ini untuk bangun jembatan jembatan e gak onok, yo sampean seneni. Wong pak camat pengawas kok. Gak gelem diseneni? Sampean laporno neng inspektorat. Betul ndak? Inspektorat ngerti sek gak gelem dandani, laporno neng kejaksaan. Ewhhhh. Itu memang kewenangan, monitoring, ya tapi jangan sampai menghalang-halangi maksudnya ya. Jadi, namanya akuntabel dan transparan itu dipermudah tapi bertanggungjawab. Pembuatan RAB seringkali di takeover oleh operator".

Tugas camat yang memverifikasi SPP sering menjadi ganjalan bagi desa untuk mencairkan dana, karena tidak semua camat ada di kantor kecamatan setiap hari. Untuk mengambil uang di Bank Bendahara desa harus melengkapi lagi dengan RAB.

Tugas Dinas PMD sesuai dengan Peraturan Bupati Nganjuk Nomor 41 Tahun 2016 yaitu melaksanakan urusan pemerintahan dan tugas pembantuan di bidang pemberdayaan masyarakat dan desa, yaitu perumusan kebijakan teknis dibidang Pemberdayaan Masyarakat dan Desa; pelaksanaan kebijakan teknis urusan pemerintahan di bidang Pemberdayaan Masyarakat dan Desa; pelaksanaan evaluasi dan pelaporan di bidang Pemberdayaan Masyarakat dan Desa; dan pelaksanaan administrasi Dinas Pemberdayaan Masyarakat dan Desa; Biro Hukum sebagai koordinator Tim Evaluasi Peraturan Desa yang bertugas menetapkan hasil evaluasi Rancangan APB Desa.

Tugas Inspektorat Kabupaten Nganjuk sesuai dengan Peraturan Bupati Nganjuk Nomor 41 Tahun 2016 yaitu: perumusan kebijakan teknis bidang pengawasan dan fasilitasi pengawasan; pelaksanaan pengawasan internal terhadap kinerja dan keuangan melalui audit, review, evaluasi, pemantauan, dan kegiatan pengawasan lainnya; pelaksanaan pengawasan untuk tujuan tertentu atas penugasan Bupati; penyusunan laporan hasil pengawasan dan pelaksanaan administrasi inspektorat.
Tabel 4

Tugas Camat, Dinas PMD, Biro Hukum dan Inspektorat

\begin{tabular}{|c|c|c|}
\hline No & Posisi & Tugas \\
\hline 1 & Camat & $\begin{array}{l}\text { Kewenangan } \\
\text { melakukan Evaluasi } \\
\text { Rancangan Peraturan } \\
\text { Desa Tentang APB } \\
\text { Desa }\end{array}$ \\
\hline 2 & $\begin{array}{l}\text { Dinas } \\
\text { PMD }\end{array}$ & $\begin{array}{l}\text { Perumusan, Pelaksana- } \\
\text { an, evaluasi dan pe- } \\
\text { laporan Pengelolaan } \\
\text { Keuangan desa serta } \\
\text { penganggaran } \\
\text { kegiatan }\end{array}$ \\
\hline 3 & $\begin{array}{l}\text { Biro } \\
\text { Hukum }\end{array}$ & $\begin{array}{l}\text { Koordinator Tim Eva- } \\
\text { luasi Peraturan Desa } \\
\text { yang bertugas me- } \\
\text { netap kan hasil eva- } \\
\text { luasi Rancangan APB } \\
\text { Desa }\end{array}$ \\
\hline 4 & Inspektorat & $\begin{array}{l}\text { Pengawasan internal } \\
\text { terhadap kinerja dan } \\
\text { keuangan melalui } \\
\text { audit, review, evaluasi, } \\
\text { pemantauan keuangan } \\
\text { desa }\end{array}$ \\
\hline
\end{tabular}

\section{Kemampuan Operator Desa Mengoperasi- kan Sistem (SILOKDES)}

Operator Desa adalah operator yang bertanggung jawab atas semua peralatan yang ada dalam sistem komputerisasi, memeriksa dan mencoba komputer dan peralatan lain apakah dapat dipergunakan sebagaimana mestinya dan menonfungsikan peralatan bila tidak dipergunakan, membuat catatan tentang pelaksanaan jadwal kegiatan penggunaan komputer, membuat backup dari sejumlah file yang ada dan pengawasan dari file backup tersebut serta bertanggung jawab atas kebersihan dan kerapihan ruang computer, sekaligus bertugas melaksanakan input data dari sumber data keuangan desa untuk diakses kedalam media komputer.

Operator desa sesungguhnya adalah orang yang bertanggung jawab untuk me- 
mantau dan mengendalikan sistem komputer sistem komputer. Tanggung jawabnya meliputi masalah perangkat lunak dan masalah hardware, pemantauan batch processing, mempertahankan dan meningkatkan kinerja sistem dan ketersediaan online, menjaga semua sistem dan dokumentasi aplikasi, dan membantu personel dengan masalah komputer.

Namun pada kenyataanya operator desa kabupaten nganjuk bukan sekedar mengoperasikan computer, mereka juga terlibat dalam RPJMDes, RKPDes, Design dan RAB serta APBDes. Meraka jua mengelola, melaksanakan, melaporkan dan mempertanggungjawabkan pengelolaan keuangan desa. Selama kurun waktu 2015-2017 semua operator desa mampu mengoperasikan SILOKDES sebelum berganti dengan SISKEUDES. Operator desa menjadi ujung ujung tombak pengelolaan keuangan desa. Hasil wawancara kami dengan salah satu operator desa (Puguh, Desa Gondang) menyatakan "Sebenarnya tidak sulit karena hanya memasukan data berupa RAB. Data itu diperoleh dari hasil kesepakatan antara pemerintah desa dengan aparat terkait yang ada di desa,". "Kami sesama operator di Kecamatan saling mengisi antara yang satu dengan yang lain. Saling mengingatkan kalau ada kendala yang dihadapi"

Operator desa yang lain (Bu Umi, Desa Joho) menyatakan sebagai berikut: “Terus terang tugas kami sangat berat, disamping harus mengimput data keuangan desa ke siskeudes, kami juga harus menyusun anggaran, melaksanakan, serta mempertanggungjawabkan bukti transaksi, seharusnya tugas menyusun anggaran itu pak sekdes, pelaksanaan dan pertanggungjawaban oleh panitia"

Dengan kecanggihan teknologi seperti pada saat ini, masing-masing kecamatan memiliki media komunikasi dan pendampingan lewat WhatsApp. Media ini sangat membantu untuk berbagi informasi, konsultasi problem software dan teknis pengelolaan keuangan desa.

\section{Kelengkapan Peraturan Pengelolaan Keu- angan Desa}

Pembangunan dan pemberdayaan masyarakat desa yang dilakukan Pemerintah Kabupaten Nganjuk mendapatkan apresiasi Pemerintah Republik Indonesia. Apresiasi itu diwujudkan dalam pemberian anugerah Desa Membangun Indonesia dari Menteri Desa Pembangunan Daerah Tertinggal dan Transmigrasi untuk Pemkab Nganjuk pada Tahun 2015 (http://pdiperjuangan-jatim. com/nganjuk-raih-anugerah-desa membangun-indonesia/). Anugerah desa membangun ini masuk dalam kategori Pembina Kabupaten Terbaik dalam Regulasi Pembangunan dan Pemberdayaan Masyarakat Desa. Anugerah ini merupakan hasil kerja keras Dinas PMD (dulu Bapemaspemdes). Dinas PMD Kabupaten Nganjuk merupakan salah satu Dinas yang aktif membuat Peraturan Bupati, Keputusan Bupati maupun Surat Edaran Sekretaris Daerah.

Namun terkait dengan perbub ini masih ada yang perlu dibenahi seperti hasil wawancara dengan Pak Parman (Pendamping Ahli) Kabupaten Nganjuk: “di Perbup kewenangan, pembangunan sarana prasarana kantor desa. Itu masuk dibidang pemerintahan di Siskeudes itu masuk dibidang Pembangunan".

Hal ini mengindikasikan adanya perbedaan persepsi antara Permendagri 114 tahun 2014 dengan Permen DPDTT Nomor 19 Tahun 2017 tentang Penetapan Prioritas DD Tahun 2018 sehingga menimbulkan kebingungan daerah dalam mengelompokkan kegiatan di SISKEUDES.

Peraturan Bupati terkait dengan dengan Pengelolaan Keuangan Desa diatur berdasarkan Peraturan Bupati Nganjuk Nomor 11 Tahun 2015 Tentang Pengelolaan Keuangan Desa Peraturan Bupati Nganjuk Nomor 36 Tahun 2016 Tentang Penghasilan Tetap, Tunjangan, Tambahan Tunjangan, Dan Penerimaan Lain Yang Sah Bagi Kepala Desa Dan Perangkat Desa. Alokasi Dana Desa diatur dengan Peraturan Bupati Nganjuk Nomor 7 Tahun 2017 Tentang Tata Cara Pengalokasian, Pembagian, Penyaluran 
Dan Pengelolaan Alokasi Dana Desa Tahun Anggaran 2017. Dana Desa diatur dengan Peraturan Bupati Nganjuk Nomor 6 Tahun 2017 Tentang Tata Cara Pembagian Dan Penetapan Besaran Dana Desa Setiap Desa Tahun Anggaran 2017. Standar Penyusunan APBDesa diatur dengan Surat Edaran Bupati Nganjuk Nomor: 141/411.304/2016 Tentang Pedoman Penyusunan APB Desa Tahun Anggaran 2017 dan Surat Edaran Sekretaris Daerah Nganjuk Nomor: 141/411.304/2016 Tentang Pedoman Penyusunan APB Desa Tahun Anggaran 2017.

Standar Satuan Harga diatur dengan Keputusan Bupati Nganjuk Nomor: 188/ 135/K/411.013/2016 tentang Penetapan Standar Satuan Harga bahkan Software Keuangan Desa (SILOKDES) juga diatur Surat Edaran Sekretaris Daerah Nganjuk Nomor: 141/411.307/2017 Tentang Pedoman Penggunaan Aplikasi Silokdes, Penganggaran Penghasilan Tetap Dan Tunjangan, serta Kegiatan Desa Sehat. Satu-satunya yang belum diatur yaitu Pengadaan Barang dan Jasa. Pengadaan Barang dan Jasa mengacu pada Perka LKPP Nomor 13 Tahun 2013 tentang Tata Cara Pengadaan Barang dan Jasa di Desa dan Peraturan Kepala LKPP Nomor 22 Tahun 2015 tentang Perubahan Atas Peraturan Kepala Lembaga Kebijakan Pengadaan Barang/Jasa Pemerintah Nomor 13 Tahun 2013 Tentang Pedoman Tata Cara Pengadaan Barang/Jasa di Desa.

\section{Tabel 5}

\section{Daftar Peraturan Pengelolaan Keuangan} Desa

\begin{tabular}{lll}
\hline No & Topik & \multicolumn{2}{c}{ Nganjuk } \\
1 & Pengelola & Peraturan Bupati \\
& an & Nganjuk Nomor 11 \\
& Keuangan & Tahun 2015 Tentang \\
& Desa & Pengelolaan Keuangan \\
& & Desa. Peraturan Bupati \\
& & Nganjuk Nomor 36 \\
& & Tahun 2016 Tentang \\
& & Penghasilan Tetap, \\
& & Tunjangan, Tambahan
\end{tabular}

Tunjangan, Dan Penerimaan Lain Yang Sah Bagi Kepala Desa Dan Perangkat Desa.

2 ADD

Peraturan Bupati Nganjuk Nomor 7 Tahun 2017 Tentang Tata Cara Pengalokasian, Pembagian, Penyaluran Dan Pengelolaan Alokasi Dana Desa Tahun Anggaran 2017.

3 Dana

Desa

Peraturan Bupati Nganjuk Nomor 6 Tahun 2017 Tentang Tata Cara Pembagian Dan Penetapan Besaran Dana Desa Setiap Desa Tahun Anggaran 2017.

4 Pengadaa Perarturan Kepala LKPP n Barang Nomor 13 Tahun 2013 dan Jasa tentang Tata Cara Pengadaan Barang dan Jasa di Desa. Peraturan Kepala LKPP Nomor 22 Tahun 2015 tentang Perubahan Atas Peraturan Kepala Lembaga Kebijakan Pengadaan Barang atau Jasa Pemerintah Nomor 13 Tahun 2013 Tentang Pedoman Tata Cara Pengadaan Barang atau Jasa di Desa.

5 Standar Surat Edaran Bupati Penyusun Nganjuk Nomor: 141/ an 411.304/2016 Tentang APBDesa Pedoman Penyusunan APB Desa Tahun Anggaran 2017. Surat Edaran Sekretaris Daerah Nganjuk Nomor: 141/411.304/2016 Tentang Pedoman Pe- 


\begin{tabular}{lllr} 
& & \multicolumn{2}{l}{ nyusunan APB Desa } \\
Tahun Anggaran 2017. \\
Standar & Keputusan Bupati \\
Satuan & Nganjuk Nomor: \\
Harga & $188 / 135 / K /$ 411.013/ \\
& 2016 tentang Pene- \\
& tapan Standar Satuan \\
& Harga. \\
& & \\
Software & Surat Edaran Sekre- \\
Keuangan & taris Daerah Nganjuk \\
Desa & Nomor: 141/411.307/ \\
& 2017 Tentang Pedoman \\
& Penggunaan Aplikasi \\
& Silokdes, Pengang- \\
& garan Penghasilan \\
& Tetap Dan Tunjangan, \\
& serta Kegiatan Desa \\
& Sehat.
\end{tabular}

\section{Ketidakpatuhan tehadap Siklus dan Keterlambatan Pencairan Dana}

Dalam PP No. 43 tahun 2014 telah diatur siklus anggaran desa yang mirip dengan siklus anggaran pada APBN maupun APBD, sebagai berikut: 1). Musyawarah Desa dilaksanakan paling lambat bulan Juni (pasal 114), 2). RKPDesa harus mulai dibahas pada bulan Juli dan ditetapkan paling lambat pada bulan September (pasal 118). 3). Rancangan Peraturan Desa mengenai APBDesa disepakati paling lambat Oktober (pasal 101), 4). Penetapan APBDesa dilakukan paling lambat pada 31 Desember (pasal 101). Pada kenyataannya, tidak ada satupun desa yang disampling oleh tim kajian dapat mengikuti siklus anggaran yang ditetapkan dalam regulasi. Bahkan dengan adanya perubahan PP No. 60 tahun 2014, desa menunda penyusunan APBDesanya. Baru April 2017 semua desa bisa menetapkan APBDesanya, meski dana desa untuk kabupaten Nganjuk tersebut sudah dicairkan oleh Pemerintah Pusat. Keterlambatan pengesahan APBDesa ini tentunya berdampak pada kinerja pembangunan di desa. Dari hasil pendalaman kepada perangkat desa dan kecamatan, hal ini lebih disebabkan karena informasi dari Pemerintah Pusat dan Pemerintah Daerah terkait rencana pembangunan di desa tersebut dan terutama besaran anggaran yang akan diperoleh desa telat diperoleh atau keputusannya berubahubah dan baru diterima bulan Februari 2017. Berbagai informasi yang dibutuhkan desa untuk memulai proses perencanaan baru diperoleh pada bulan Januari sampai dengan April tahun berikutnya. Akibatnya, pelaksanaan siklus anggaran di desa jauh melenceng dari waktu yang ditetapkan dalam regulasi

Dampak dari mundurnya waktu siklus pengelolaan anggaran desa sulit dipatuhi oleh desa ini salah satunya yaitu keterlambatan pencairan dana. Keterlambatan pencairan APB Desa karena disebabkan banyaknya desa yang belum menyerahkan persyaratan salah satunya APB Desa sehingga terealisasi bulan Mei 2017. Faktor kedua keterlambatan pencairan dana tahap kedua. Kepala Dinas PMD Nganjuk menjelaskan alasan terlambatnya transfer Dana Desa (DD) tahap II disebabkan sejumlah desa terlambat menyetor laporan realisasi DD tahap I yang dikelola. Sementara itu, ketentuan Kemenkeu, laporan realisasi tahap I tersebut harus $50 \%$ total transfer tahap I ke Kemenkeu sebelum transfer tahap II diturunkan ke Kas Daerah. Hasil wawancara dengan Kepala Dinas (Bu Widaryati Dhalilah): "Ini jadi masalah, karena ada desa cepat, tapi ada juga lambat masukkan laporan, sehingga yang lambat ini mengganggu laporan secara utuh,"

Kepala Dinas PMD mengakui alokasi anggaran DD tahap pertama sebenarnya sudah ditransfer Kemenkeu ke rekening kas umum daerah (RKUD). Namun pihaknya masih belum bisa mencarikan karena masih ada desa yang belum memenuhi persyaratan pencairan. Lebih lanjut Kepala Dinas PMD menyampaikan: 'Kami masih menunggu beberapa desa untuk mengajukan persyaratan pencairan. Kalau persyaratan belum masuk semua, pencairan juga belum bisa dilakukan karena ini memang menjadi salah satu persyaratnya". 


\section{Kapasitas dan Personalia}

Problem utama kapasitas dan personalia ini salahsatunya masih banyaknya Kades dan Perangkat Desa yang belum memahami bagaimana menyusun RPJMD, Renstra, Renja, APBDesa yang fungsi utamanya sebagai dokumen perencanaan yang akan menjadi acuan dalam menyelenggarakan pemerintahan desa. Lemahnya dari sisi perencanaan ini berakibat pada tidak maksimalnya kinerja pemerintahan desa, karena kegiatan yang dilaksanakan tidak bersumber dari analisa perencanaan kebutuhan desa yang tepat, sehingga tidak memberikan dampak yang besar bagi masyarakat desa. Salah seorang operator desa Bu Linda (Desa Berbek) menyatakan: "saya mengelola semua pengelolaan keuangan desa, padahal sebenarnya saya tidak terlalu mengerti, saya belum pernah ikut pelatihan keuangan desa sebelumnya, apa itu Undang-undang, Permendagri atau Permendesa belum tahu bedanya apa"

Mengelola keuangan desa tidak hanya mengandalkan kuasa kepala desa dan perangkatnya. Tetapi butuh keterlibatan berbagai stakeholders yang ada di desa. Apalagi saat ini desa telah mengelola dana dalam jumlah besar. Untuk itu, desa perlu memiliki orang yang mahir agar membantu menyusun RPJMDes, RKPDes, Design \& RAB serta APBDes.

Selama ini, Design dan RAB serta dokumen lainnya disusun asal jadi. Tata cara dan kaidah teknis atau unsur akademis selalu diabaikan. Yang diutamakan oleh pemerintah desa adalah formalitasnya. Soal kebenaraan isi, itu urusan kemudian. Bagi mereka yang penting target bisa tercapai. Jadi bukan proses yang mereka perhatikan. Menurut salah seorang pendamping desa (kecamatan) Pak Tamim: "sesuai dengan pengamatan saya, yang betul-betul mengerti design dan RAB gambar, terutama untuk pemabangunan hanya segelintir orang, selebihnya yang penting Digambar untuk memenuhi persyaratan pengajuan dan pencairan dana, soale kalau tidak ada pak camat tidak mau tanda tangan"
Bagaimana mungkin kita mengelola dana dalam jumlah besar, sementara membelanjakan bahan, alat, dan upah tidak ada yang hitung RAB-nya. Pengalaman selama ini, yang terlibat bersama PNPM-MPd, sulit sekali menemukan kader teknik atau warga yang memiliki kemampuan dan komitmen tinggi untuk mau belajar menguasai bidang teknik. Persoalan yang sering kita temukan di lapangan adalah masih banyak administrasi pelaporan dan pertanggungjawaban yang belum dikerjakan, misalnya LPPD maupun LKPj.

PADes sangat minim, antara lain karena Desa tidak mempunyai kewenangan dan kapasitas untuk menggali potensi sumbersumber keuangan Desa. Karena terbatas, anggaran Desa tidak mampu memenuhi kebutuhan kesejahteraan perangkat Desa, pelayanan publik, pembangunan Desa apalagi kesejahteraan masyarakat Desa. Anggaran Desa sangat tidak mencukupi untuk mendukung pelayanan dasar seperti pendidikan, kesehatan dan perumahan. Dengan kalimat lain ada kesenjangan fiskal antara keuangan pemerintah supraDesa dengan pemerintah Desa.

\section{Pembangunan tidak berbasis padat karya dan tidak sepenuhnya menggambarkan kebutuhan yang diperlukan desa}

Penetapan prioritas penggunaan dana desa didasarkan pada prinsip swakelola dan berbasis sumber daya desa mengutamakan pelaksanaan secara mandiri dengan pendayagunaan sumberdaya alam desa, mengutamakan tenaga, pikiran dan keterampilan warga desa dan kearifan lokal. Penggunaan dana desa paling sedikit sebesar 30 persen wajib digunakan untuk menciptakan lapangan kerja di desa dan membayar upah. Program padat karya mampu meningkatkan penghasilan masyarakat desa yang pada gilirannya terwujud kesehateraan masyarakat desa. Dengan skema ini maka mulai dari pembelian material, tenaga kerja, dan perputaran Dana Desa tersebut berimbas terhadap masyarakat desa. Salah satu penyebab pembangunan tidak berbasis 
padat karya dan tidak sepenuhnya menggambarkan kebutuhan yang diperlukan desa disebabkan oleh ketidaktahuan dan ketidak mampuan desa mengelola anggaran, kurangnya kompetensi petugas pendamping, dan kurangnya pengembangan teknis pengelolaan anggaran yang sesuai dengan anggaran nasional ke desa.

Hasil wawancara dengan Pak Nurdian (Staf PMD): “Jujur terus terang pak, masih banyak desa yang pembangunannya tetap sama dengan tahun lalu, lha wong setiap tahun mendapatkan dana hampir 1 Milyar kok pembangunannya tidak tampak dan kondisi desa tetap tidak ada perubahan. Beberapa saya tanya kenapa pembangunan melibatkan pihak ketiga jawaban meraka karena biar lebih mudah SPJnya".

Hasil wawancara dengan Pak Parman (Penamping Ahli): "sebenarnya kita dari pendamping sudah tahu. Pembangunan di Desa tidak sepenuhnya jujur sesuai dengan yang dilaporkan. Banyak yang mengusulkan perbaikan gapura desa, tetapi tahun berikutnya mengusulkan perbaikan gapura lagi, ada juga yang mengerjakan proyek sudara sendiri".

Kegiatan pembangunan di desa sering melibatkan pihak ketiga (kontraktor). Hal ini dilakukan oleh PTPKD karena adanya tekanan dari kepala desa dan untuk menyembunyikan nilai proyek yang sesungguhnya kepada masyarakat. Masyarakat tidak bisa mengawasi secara langsung pembelajaaan maupun pengeluaran dana.

\section{Transparansi rencana penggunaan dan pertanggungjawaban APBDesa Masih Rendah}

Ada kesenjangan antara tanggungjawab dan responsivitas dengan partisipasi masyarakat dalam anggaran Desa. Partisipasi masyarakat dalam anggaran pembangunan Desa sangat besar, sementara tanggungjawab dan responsivitas sangat kecil. Sebagian besar anggaran pembangunan Desa, terutama pembangunan fisik (infrastruktur), ditopang oleh gotongroyong atau swadaya masyarakat. Menurut
Pak Suparman (Pendamping ahli) Kabupaten Nganjuk: "yang membuat APB Desa itu yang sekretaris desa, sebagian malah yang buat operator desa, sangat sedikit pembuatan APB Desa yang melibatkan warga desa, bahkan BPD hanya tukang stempel saja, sehingga penggunaan APB Desa masih untuk kepentingan peragkat desa".

Sementara besaran dana dari pemerintah sangat kecil, yang difungsikan sebagai stimulan untuk mengerahkan (mobilisasi) dana swadaya masyarakat. Padahal kekuatan dana dari warga masyarakat sangat terbatas, mengingat sebagian besar warga Desa mengalami kesulitan untuk membiayai kebutuhan dasar (papan, sandang, pangan, pendidikan dan kesehatan) bagi keluarganya masing-masing.

\section{Pembahasan Hasil Penelitian}

Strategi implementasi aplikasi sistem keuangan desa pada pemerintah daerah kabupaten Nganjuk dengan menggunakan workshop ini sangat efektif dan efisien. Hal ini sesuai dengan hasil penelitian Setyorini et al. (2017) dengan menggunakan desain eksperimen. Hasil penelitian ini pelatihan keuangan desa dapat meningkatkan pemahaman aparatur desa sehingga mampu memberikan pelayanan maksimal kepada masyarakat sehingga tercipta good village government.

Problematika pengelolaan keuangan desa Kabupaten Nganjuk terbagi menjadi 2 hal yaitu aspek positif dan aspek negative. Aspek positif meliputi Sinergi Antara Camat, Dinas PMD, Biro Hukum dan Inspektorat, Kemampuan Operator Desa Mengoperasikan Sistem (SILOKDES), Kelengkapan Peraturan Pengelolaan Keuangan Desa. Aspek positif ini sangat mendukung prestasi Kabupaten Nganjuk berupa penghargaan mendapatkan anugerah Desa Membangun Indonesia dari Menteri Desa Pembangunan Daerah Tertinggal dan Transmigrasi untuk Pemkab Nganjuk pada Tahun 2015. Namun dalam hal Kelengkapan Peraturan Pengelolaan Keuangan Desa 
masih ada kurang singkronisasi antara perbub Kab Nganjuk dengan Permendagri.

Aspek negative meliputi Ketidakpatuhan tehadap Siklus dan Keterlambatan Pencairan dana, Kapasitas dan Personalia, Pembangunan tidak berbasis padat karya dan tidak sepenuhnya menggambarkan kebutuhan yang diperlukan desa, dan Transparansi rencana penggunaan dan pertanggungjawaban APBDesa Masih Rendah. Terkait dengan rendahnya transparansi rencana penggunaan dan pertanggungjawaban APB Desa Masih Rendah. Hal ini disebabkan karena adanya masalah seperti tidak terbukanya pemerintah dan tidak mudahnya diakses sehingga masyarakat tidak mengetahui mengenai anggaran yang terpakai, selain itu transparansi ini sering tidak terrealisasi sebagaimana mestinya kerena rendahnya pengaruh aparatur desa terhadap pengembangan dan pengelolaan alokasi dana desa ini menjadi faktor penghambat transparansi pengelolaan anggaran pendapatan dan belanja desa (Amirruddin et al., 2012).

Hasil penelitian ini tidak sesuai dengan Hasniati (2016), Bustamam et. al (2018), Simangunsong dan Wicaksono (2017), dan Nurhakim dan Yudianto (2018). Hasniati (2016) meneliti Desa Sampulungan Kecamatan Galesong Utara Kabupaten Takalar. Hasil penelitian Hasniati (2016), menunjukkan bahwa pengelolaan dana desa, mulai dari perencanaan, pelaksanaan dan pelaporan kegiatan telah memenuhi prinsip akuntabilitas. Model yang dikembangkan berdasarkan hasil penelitian ini diberi nama Model Akuntabilitas Proses. Akuntabilitas proses dalam pengelolaan dana desa adalah kesediaan dari para pengelola dana desa untuk menerima tanggung jawab atas apa yang ditugaskan kepadanya secara efisien, efektif, berkeadilan, dan dilaksanakan secara transparan dengan melibatkan masyarakat.

Hasil penelitian ini sesuai dengan hasil penelitian Juwaini et al. (2018). Salah satu yang menyebabkan keterlambatan pelaporan karena adanya problem dalam pembayaran karena perhitungan pajak meng- gunakan aplikasi SISKEUDES yang salah. Ketidakpatuhan tehadap Siklus dan Keterlambatan Pencairan dana hampir terjadi di setiap daerah. Hasil kajian Komisi Pemberantasan Korupsi (2015) tidak ada satupun desa yang disampling oleh tim kajian dapat mengikuti siklus anggaran yang ditetapkan dalam regulasi. Dari hasil pendalaman kepada perangkat desa dan kecamatan, hal ini lebih disebabkan karena informasi dari Pemerintah Pusat dan Pemerintah Daerah terkait rencana pembangunan di desa tersebut dan terutama besaran anggaran yang akan diperoleh desa telat diperoleh atau keputusannya berubahubah. Demkikian juga dengan Kabupaten Nganjuk Pagu Indikatif Kabupaten baru diberikan pada bulan Februari, sehingga pada bulan Maret baru bisa menyelesaikan penyusunan APB Desa.

\section{SIMPULAN DAN SARAN}

Strategi implementasi aplikasi sistem keuangan desa pada pemerintah daerah kabupaten Nganjuk dengan menggunakan workshop ini sangat efektif dan efisien. Workshop I meletakkan dasar penggunaan SISKEUDES, sementara workshop dan pendampingan II memberikan fasilitas pendampingan, konsultasi dan mereview kembali materi yang belum jelas pada workshop pengelolaan keuangan desa I. Problematika pengelolaan keuangan desa Kabupaten Nganjuk terbagi menjadi 2 hal yaitu aspek positif dan aspek negatif. Aspek positif meliputi sinergi antara camat, dinas pmd, biro hukum dan inspektorat, kemampuan operator desa mengoperasikan sistem (SILOKDES), kelengkapan peraturan pengelolaan keuangan desa. Aspek negatif meliputi ketidakpatuhan tehadap siklus dan keterlambatan pencairan dana, kapasitas dan personalia, pembangunan tidak berbasis padat karya dan tidak sepenuhnya menggambarkan kebutuhan yang diperlukan desa, dan transparansi rencana penggunaan dan pertanggungjawaban APBDesa Masih Rendah. Keterbatasan dan saran penelitian berikutnya yaitu penelitian ini dilakukan 
dengan pendekatan observasi selama workshop dan hasil wawancara dengan stakeholder desa, penelitian lebih lanjut bisa ditindaklanjuti dengan melakukan pengawasan dan pendampingan riil di desa. Tahun 2017 Kabupaten Nganjuk masih menggunakan dual system yaitu SILOKDES dan SISKEUDES. Hal ini membuat konsentrasi operator desa terpecah. Seharusnya ada kebijakan migrasi software dari SILOKDES dan SISKEUDES setelah workshop agar operator desa betul-betul belajar dan bertanggungjawab.

\section{DAFTAR PUSTAKA}

Badaruddin, B. dan E. Ermansyah. 2017, Proposing a Model for Law Number 6 of 2014: Evidence from North Sumatra, International Journal of Economic Perspectives 11(4): 188-198.

Badaruddin, B. dan E. Ermansyah. 2018, The Model of Implementing Law Number 6 of 2014 on Village of Social CapitalBased: Evidence from North Sumatra, Journal of Economic \& Management Perspectives 12(2): 531-541.

Bustamam, E. Amalia, Jalaluddin. 2018. A Performance Analysis of Village Fund Management: A Case Study in Lut Tawar District-Indonesia. Journal of Accounting Research, Organization and Economics 1(2): 112-121.

Deardorff, D. S. and G. Williams. 2006. Synergy Leadership in Quantum. Organizations. Fesserdorff Consultants.

Fajri, Rahmi. 2015. The Government Accountability Village in the Village Fund Allocation Management (ADD) (Study on Ketindan Village Office, District Lawang, Malang). Journal of Public Administration (JAP) 3(7): 10991104.

Fauzi, Asni 2013 The management of the village fund allocation as an instrument towards Economic Independence Village (Case Studies in 2 villages in Siak Regency, Province Riau). IOSR Journal of Business and Management (IOSR-JBM)
Ferina, 2016. IS Readiness Review the Implementation of the Village Government Minister Regulation No. 113 on Rural Financial Management (Case Study on Village Government in Ogan Hir). Journal of Management and Business Sriwijaya 14(3): 321-336.

Hasniati. 2016. Model Akuntabilitas Pengelolaan Dana Desa. Jurnal Analisis dan Pelayanan Publik 2(1): Juni

Juwaini, I., Akram, L. H. Husnan. 2018. Optimization of Village Financial System (Siskeudes) for Village Financial Administration (Case Study in Dompu Village Government, Indonesia). International Journal of Economics, Commerce and Management United Kingdom VI(7): July 2018.

Keputusan Bupati Nganjuk Nomor: 188/ 135/K/411.013/2016 tentang Penetapan Standar Satuan Harga

Khusniyatun, S., dan Kiswanto. 2017, The Determinant of Financial Management Accountability of The Village (A Study on Village Government in the Area of Kebumen District). Accounting Analysis Journal 6(1): 10-18.

Komisi Pemberantasan Korupsi. 2015. Laporan Hasil Kajian Pengelolaan Keuangan Desa: Alokasi Dana Desa dan Dana Desa

Lewis, B.D., 2015. Decentralising to villages in Indonesia: money (and other) mistakes: decentralising to villages in Indonesia. Public Adm. Dev. 35, 347-359. https://doi. org/10.1002/pad.1741.

Meng, H., 2013, Analysis of the exist problem of subdistrict office financial management, Chinese Agricultural Accounting 04: 52-55.

Nurhakim, I., I. Yudianto. 2018. Implementation of Village Fund Management in Panyirapan Village, Sukanagara Village and Soreang Village, Soreang SubDstrict, Bandung Regency. Journal of Accounting Auditing and Business (ISSN: 2614-3844) 2(2): 2018 
Peraturan Bupati Nganjuk Nomor 11 Tahun 2015 Tentang Pengelolaan Keuangan Desa

Peraturan Bupati Nganjuk Nomor 3 Tahun 2015 Tentang Pedoman Pengelolaan Pasar Desa.

Peraturan Bupati Nganjuk Nomor 32 Tahun 2016 Tentang Susunan Organisasi Dan Tata Kerja Pemerintah Desa.

Peraturan Bupati Nganjuk Nomor 35 Tahun 2016 Tentang Kewenangan Desa Berdasarkan Hak Asal-usul Dan Kewenangan Lokal Berskala Desa.

Peraturan Bupati Nganjuk Nomor 36 Tahun 2016 Tentang Penghasilan Tetap, Tunjangan, Tambahan Tunjangan, Dan Penerimaan Lain Yang Sah Bagi Kepala Desa Dan Perangkat Desa.

Peraturan Bupati Nganjuk Nomor 6 Tahun 2017 Tentang Tata Cara Pembagian Dan Penetapan Besaran Dana Desa Setiap Desa Tahun Anggaran 2017.

Peraturan Bupati Nganjuk Nomor 7 Tahun 2017 Tentang Tata Cara Pengalokasian, Pembagian, Penyaluran Dan Pengelolaan Alokasi Dana Desa Tahun Anggaran 2017.

Peraturan Kepala LKPP Nomor 13 Tahun 2013 tentang Tata Cara Pengadaan Barang dan Jasa di Desa.

Peraturan Kepala LKPP Nomor 22 Tahun 2015 tentang Perubahan Atas Peraturan Kepala Lembaga Kebijakan Pengadaan Barang/Jasa Pemerintah Nomor 13 Tahun 2013 Tentang Pedoman Tata Cara Pengadaan Barang/Jasa di Desa.

Peraturan Pemerintah No 60 Tahun 2014 Dana Desa yang bersumber dari Anggaran Pendapatan dan Belanja Negara. 21 Juli 2014. Lembaran Negara Republik Indonesia Tahun 2014 Nomor 168. Jakarta.

Peraturan Pemerintah Republik Indonesia Nomor 43 tahun 2014 Peraturan Pelaksanaan Undang Undang Nomor 6 Tahun 2014 Tentang Desa. 30 Mei 2014. Lembaran Negara Republik Indonesia Tahun 2014 Nomor 123. Jakarta.
Peraturan Presiden Republik Indonesia Nomor 22 Tahun 2015 Perubahan atas Peraturan Pemerintah No 60 Tahun 2014 tentang Dana Desa yang bersumber dari Anggaran Pendapatan dan Belanja Negara. 29 April 2015. Lembaran Negara Republik Indonesia Tahun 2015 Nomor 88. Jakarta.

Sembiring, R., E. Herlinda, dan S. Ningsih. 2017, Implementation of Autonomy Area through the Implementation of Village Authority, International Journal of Economic Perspectives 11(3): 5-11.

Setyorini, C. T., D. Susilowati, W. Ramadhanti, Y. N. Farida. 2017. Analisis Efektivitas Pelatihan Keuangan Desa: Upaya Peningkatan Profesionalisme Aparatur Desa. Sustainable Competitive Advantage-7 (SCA-7) FEB UNSOED Purwokerto, 20 September 2017.

Simangunsong, F., S. Wicaksono. 2017. Evaluation of Village Fund Management in Yapen Islands Regency Papua Province (Case Study at PasirPutih Village, South Yapen District). Open Journal of Social Sciences 5: 250-268.

Surat Edaran Bupati Nganjuk Nomor: 141/411.304/2016 Tentang Pedoman Penyusunan APB Desa Tahun Anggaran 2017.

Surat Edaran Sekretaris Daerah Nganjuk Nomor: 141/411.304/2016 Tentang Pedoman Penyusunan APB Desa Tahun Anggaran 2017.

Surat Edaran Sekretaris Daerah Nganjuk Nomor:141/411.307/2017 Tentang Pedoman Penggunaan Aplikasi Silokdes, Penganggaran Penghasilan Tetap Dan Tunjangan, serta Kegiatan Desa Sehat.

Suwandi. 2015. Public Participation in Implementing Village Allocation Fund (ADD) Village Office of Suka Damai of Muara Badak Kartanegarae Kutai Regency. Journal of Public Administration 3(4): 1183-1194.

Syaifullah, M. 2017. Understanding of Village Apparatus on Implementation Accounting Villages. International Jour- 
nal of Science and Research 6(8): 11681175.

Undang-Undang Republik Indonesia Nomor Nomor 6 tahun 2004 tentang Desa. 15 Januari 2014. Lembaran Negara Republik Indonesia Tahun 2014 Nomor 7. Jakarta.

Wahyuningsih, P. dan Kiswanto. 2016. Factors Affecting The Accountability of Village Financial Management. Accounting Analysis Journal 5(3): 139-146.

Wang, Y., 2013, A Study on Problems of the Village-level Financial ManagementTaking Wenxian Xu-bao Town in Henan Province as an Example, Working Paper, Wuhan Polytechnic University.

Xiao, R., 2015. The village-level financial management mode and its optimization research, Working Paper, Southwest University of Political Science and Law.
Yi, F., 2014. The town of Changsha Lei Feng rural financial management mode of research, Working Paper, Central South University of Forestry \& Technology, 2014.

Yulihantini, D. T., \& Wardayati, S. M. 2017. Financial Accountability in The Management of Village Fund Allocation. Working Paper, In Proceeding The 1th International Conference on Business and Accounting Studies, Faculty of Economics and Business University of Jember.

Zhang, J. dan G. Wang. 2017. Research on Village-level Financial Management Mode of Lou Feng Subdistrict, Suzhou, Working Paper, 3rd International Conference on Social Science and Management (ICSSM 2017) 